Acta vet. scand. $1981,22,578-588$.

From the Department of Food Hygiene, College of Veterinary Medicine, Helsinki, Finland.

\title{
THE EFFECT OF $\mathrm{NaCl}$ ON CAMPYLOBACTER JEJUNI/COLI
}

\author{
By \\ Marja-Liisa Hänninen
}

\begin{abstract}
HÄNNINEN, MARJA-LIISA: The effect of $\mathrm{NaCl}$ on Campylobacter jejuni/coli. Acta vet. scand. 1981, 22, 578-588. - The growth of 2 strains of Campylobacter jejuni/coli was investigated in $0-2.0 \%$ $\mathrm{NaCl}$ in Brucella broth at $35^{\circ} \mathrm{C}$ and $30^{\circ} \mathrm{C}$. Both strains tolerated more $\mathrm{NaCl}$ in the growth medium at $35^{\circ} \mathrm{C}$ than at $30^{\circ} \mathrm{C} .2 \% \mathrm{NaCl}$ was bacteriocidic at both temperatures. The strains also grew in the medium without added $\mathrm{NaCl}$. At $35^{\circ} \mathrm{C}$, low concentrations of $\mathrm{NaCl}$ stimulated the growth of strain 5616, but not the growth of strain B33. At $30^{\circ} \mathrm{C}$, strain 5616 grew in $\mathrm{NaCl}$ concentrations up to $1.0 \%$ and strain $\mathrm{B33}$ in $0 \%$ and at the control concentration $(0.5 \% \mathrm{NaCl})$.

The survival of $22 \mathrm{C}$. jejuni/coli strains in $2.0 \% \mathrm{NaCl}$ at $4^{\circ} \mathrm{C}$ and $35^{\circ} \mathrm{C}$ was also investigated. Human strains showed significantly greater tolerance to $2.0 \% \mathrm{NaCl}$ at both temperatures than did the strains isolated from animals. These findings suggest that the salting of food can be effective in preventing the growth or survival of C. jejuni/coli.

C. jejuni/coli; NaCl; growth; survival.
\end{abstract}

Campylobacter jejuni/coli has been implicated as a cause of human gastroenteritis. Although the epidemiology of human gastroenteritis is still partly unresolved, some epidemics have proven to be water- or food-borne (Butzler \& Skirrow 1979). C. jejuni/coli bacteria have been isolated from unprocessed foods, e.g. red meat (Butzler \& Skirrow, Stern 1981), poultry meat (Grant et al. 1980), and coastal sea water samples (Pearson et al. 1977).

Salt-tolerance has been used as a criterion in differentiating catalase-positive Campylobacter species; C. faecalis can usually grow in $3.5 \% \mathrm{NaCl}$, but $\mathrm{C}$. fetus subsp. fetus, subsp. jejuni (C. jejuni/coli), and subsp. intestinalis cannot (Smibert 1974). It has also been shown by some authors (Fletcher \& Plastridge 1964, Lawson et al. 1975, Hänninen to be publ.) that there are differen- 
ces between $\mathrm{C}$. jejuni/coli strains in salt-tolerance, if $\mathrm{NaCl}$ concentrations $2.0 \%$ or less in the cultivation medium are used.

Salt is the most widely used of food preservatives. The microbiological effect of $\mathrm{NaCl}$ as a growth inhibitor for microbial cells in food probably depends on the osmotic withdrawal of water, and will reflect the water activity of the system. The effect of salt is often similar to that of drying (Scott 1957). The lethal action of $\mathrm{NaCl}$, like that of other food preservatives, is known to be reduced at low temperatures (Ingram \& Kitchell 1967). There are also several reports which demonstrate an effect of sodium chloride in rising the minimum temperature for growth (Ingram \& MacKey 1976).

Because C. jejuni/coli has a relatively low salt-tolerance, the salt concentrations used in foods can be effective in preventing the growth or survival of Campylobacter cells. C. jejuni/coli does not grow at the temperatures commonly used for storage of perishable foods, since its minimum growth temperature is about $30^{\circ} \mathrm{C}$ (Smibert). The survival of non-growing cells of C. jejuni/ coli at low $\mathrm{NaCl}$ concentrations is not known.

The purpose of this study was to investigate the growth of C. jejuni/coli at different low $\mathrm{NaCl}$ concentrations. The tolerance of $\mathrm{C}$. jejuni/coli strains to $2.0 \% \mathrm{NaCl}$ at growth and refrigeration temperatures was also investigated.

\section{MATERIALS AND METHODS}

\section{Bacterial strains}

The bacterial strains used were isolated from human gastroenteritis $(5616,2107,12650,11299,6407,7535,9000$; isolated at the Department of Bacteriology and Immunology, University of Helsinki, by T. Kosunen. Strain NCTC 11168 was obtained from the Center for Disease Control, Atlanta, Georgia, USA). Bovine (N104, N120, N149, N191), ovine (L5B, L53, L69), chicken (B33, B42, B86, B103) and swine (S12, S14, S17) strains were isolated from intestinal contents or rectal swabs. The sources and methods of isolation are described elsewhere (Hänninen \& Raevuori 1981). After isolation the strains were stored frozen at $-20^{\circ} \mathrm{C}$.

\section{Media}

In the survival studies at $2 \% \mathrm{NaCl}, 1.5 \% \mathrm{NaCl}$ was added to dehydrated Brucella broth (Difco), filled with distilled water 
in a volumetric flask and autoclaved at $121^{\circ} \mathrm{C}$ for $15 \mathrm{~min}$. In the growth studies the Brucella broth was prepared in the laboratory: pancreatic digest of casein (Difco) $(10 \mathrm{~g})$, peptic digest of animal tissues (Difco) $(10 \mathrm{~g})$, yeast extract (Difco) $(2 \mathrm{~g})$ and sodium bisulphite (Merck) $(0.1 \mathrm{~g})$ were added to $1000 \mathrm{ml}$ of distilled water. The final $\mathrm{pH}$ of the medium was $7.0 \pm 0.1 . \mathrm{NaCl}$ was added in the appropriate concentrations to achieve final concentrations of $0.5 \%$ (concentration in the normal Brucella broth), $1 \%, 1.5 \%, 1.75 \%$ and $2.0 \%$. The media were autoclaved at $121^{\circ} \mathrm{C}$ for $15 \mathrm{~min}$. The volumes of the media were carefully tested after autoclaving to ensure that the salt concentrations had not increased during autoclaving. Only fresh media were used in the experiments.

In the determination of the Campylobacter count, Brucella agar with $7 \%$ defibrinated bovine blood was used. All the media were incubated microaerophilically $\left(85 \% \mathrm{~N}_{2}, 15 \% \mathrm{CO}_{2}\right.$ and $5 \%$ $\mathrm{O}_{2}$ ). The dilution fluid used was $0.1 \%$ peptone water.

\section{Survival and growth studies}

The inoculum for both the survival and the growth studies was prepared by adding a loopful of blood agar culture ( 2 days at $35^{\circ} \mathrm{C}$ ) to Brucella broth and incubating this microaerophilically for $40-44 \mathrm{~h}$ at $35^{\circ} \mathrm{C}$.

In the survival studies, $1 \mathrm{ml}$ of the Brucella broth culture of a C. jejuni/coli strain was inoculated into $50 \mathrm{ml}$ of Brucella broth with $2 \% \mathrm{NaCl}$ in $100 \mathrm{ml}$ glass bottles. The Campylobacter count was made immediately after inoculation and after storage for $48 \mathrm{~h}$ at $4^{\circ} \mathrm{C}$ or $35^{\circ} \mathrm{C}$ by serial tenfold dilutions in $0.1 \%$ peptone water and plating of $0.1 \mathrm{ml}$ on Brucella blood agar plates. All the experiments were duplicated.

In the growth studies, $1 \mathrm{ml}$ of the $40-44 \mathrm{~h}$ Brucella broth culture of a C. jejuni/coli strain was inoculated into $100 \mathrm{ml}$ of freshly prepared Brucella broth in a $200 \mathrm{ml}$ glass bottle containing the desired levels of sodium chloride. The inoculated Brucella broth was divided into test tubes, $5 \mathrm{ml}$ per tube, and incubated microaerophilically at $30^{\circ} \mathrm{C}$ and $35^{\circ} \mathrm{C}$. After incubation for various time periods, 2 tubes were taken for determination of the Campylobacter count as described above for survival studies.

In the statistical analysis of the results, Student's t-test was used. 

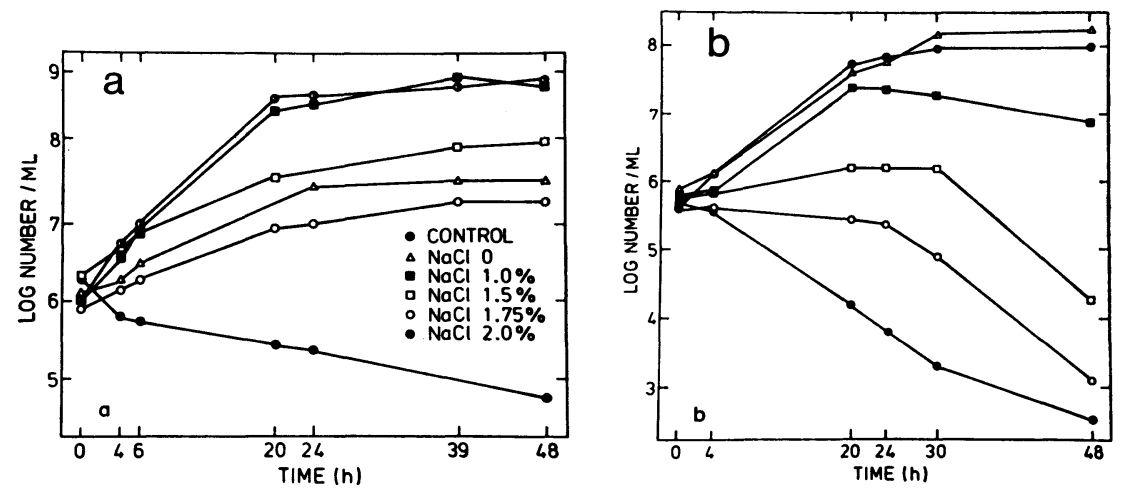

F i g u r e 1. Growth and survival of Campylobacter jejuni/coli strains 5616 (a) and $\mathrm{B} 33$ (b) at $35^{\circ} \mathrm{C}$ in Brucella broth with 0 to $2 \% \mathrm{NaCl}$.

\section{RESULTS}

The results of growth studies of $\mathrm{C}$. jejuni/coli strains 5616 and $\mathrm{B} 33$ in $\mathrm{NaCl}$ concentrations varying from $0 \%$ to $2.0 \%$ are presented in Figs. 1a, 1b, 2a, and 2b. The growth of both strains is greatly influenced by the incubation temperature. Both strains grew more slowly and tolerated less $\mathrm{NaCl}$ at $30^{\circ} \mathrm{C}$ than at $35^{\circ} \mathrm{C}$.

At $35^{\circ} \mathrm{C}$ the cells of strain 5616 were able to grow in salt concentrations 0 to $1.75 \%$. At $2 \% \mathrm{NaCl}$ the number of cells decreased during the $48 \mathrm{~h}$ incubation. The growth in $1.0 \% \mathrm{NaCl}$ was comparable with the control growth. At $1.5 \%, 1.75 \%$ and $0 \% \mathrm{NaCl}$ the $\log$ numbers of cells obtained during the growth
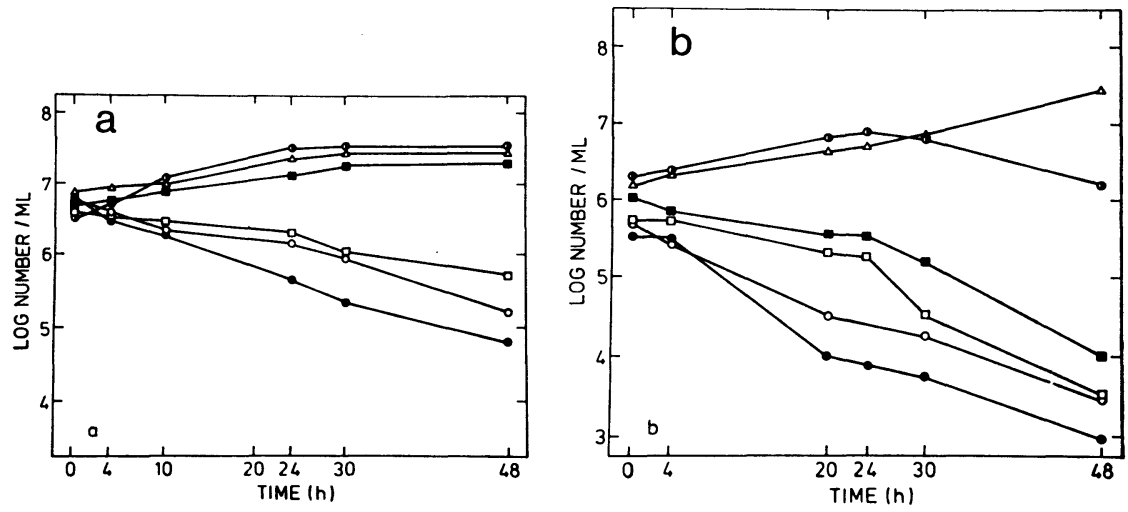

F i g u r e 2. Growth and survival of Campylobacter jejuni/coli strains 5616 (a) and $\mathrm{B} 33$ (b) at $30^{\circ} \mathrm{C}$ in Brucella broth with 0 to $2 \% \mathrm{NaCl}$. Symbols: see Fig. 1 a. 
period were lower than those of the control. The final number of cells decreased when the salt concentration increased from $1.5 \%$ to $1.75 \%$. At $35^{\circ} \mathrm{C}$ low concentrations of $\mathrm{NaCl}$ stimulated the growth of strain 5616. Strain $\mathrm{B} 33$ grew at $35^{\circ} \mathrm{C}$ in $\mathrm{NaCl}$ concentrations $0 \%$ to $1.5 \%$, although the number of cells increased onyl slightly in $1.5 \% \mathrm{NaCl}$. After about $30 \mathrm{~h}$ incubation the number of cells in $1.5 \% \mathrm{NaCl}$ decreased. $\mathrm{NaCl}$ concentrations of $1.75 \%$ and $2.0 \%$ were bacteriocidic.

At $30^{\circ} \mathrm{C}$, strain 5616 grew only in $\mathrm{NaCl}$ concentrations $0 \%$ to $1.5 \%, \mathrm{NaCl}$ concentrations $1.75 \%$ to $2.0 \%$ were bacteriocidic. The log numbers of cells obtained during incubation were almost the same in $\mathrm{NaCl}$ concentrations $0 \%$ to $\mathbf{1 . 0} \%$. For strain B33,

T a ble 1. Differences between the $\log$ numbers $/ \mathrm{ml}$ of cells of $\mathrm{C}$. jejuni/coli before and after storage at $35^{\circ} \mathrm{C}$ or $4^{\circ} \mathrm{C}$ in Brucella broth with $2 \% \mathrm{NaCl}$ for $48 \mathrm{~h}$.

\begin{tabular}{lcc}
\hline \multirow{2}{*}{ Strain } & \multicolumn{2}{c}{ Mean differences $^{1}$} \\
\cline { 2 - 3 } 5616 & $35^{\circ} \mathrm{C}$ & $4^{\circ} \mathrm{C}$ \\
\hline 2107 & 1.40 & 0.57 \\
12658 & 1,30 & 0 \\
6407 & 0.90 & 0.69 \\
NCTG 11168 & 0 & $\mathrm{ND}^{2}$ \\
7535 & 0.75 & 0.25 \\
9000 & 2.12 & $\mathrm{ND}$ \\
11299 & $\mathrm{ND}$ & 0.1 \\
B86 & 1.20 & 0.86 \\
B42 & 3.88 & 1.26 \\
B103 & 3.38 & 0.61 \\
B33 & 3.67 & 0.61 \\
N191 & 1.84 & 0.30 \\
N120 & 3.12 & 1.14 \\
N149 & 4.24 & 1.04 \\
N104 & 1.30 & 1.26 \\
S14 & 2.81 & 0.1 \\
S17 & 1.58 & 0.89 \\
S12 & 2.35 & 0.68 \\
L58 & 3.12 & 0.67 \\
L53 & 2.35 & ND \\
L69 & 1.86 & 1.66 \\
\hline
\end{tabular}

1 the log numbers of cells/ml were determined before and after incubation of cells at $35^{\circ} \mathrm{C}$ or $4^{\circ} \mathrm{C}$ for $48 \mathrm{~h}$ in duplicated bottles of Brucella broth with $2 \%$ NaCl.

$2 \mathrm{ND}=$ not determined. 
$1 \% \mathrm{NaCl}$ was bacteriocidic. The final number of cells in $0 \%$ $\mathrm{NaCl}$ was even higher than that of the control.

The results of the survival experiments of $\mathrm{C}$. jejuni/coli strains at $4^{\circ} \mathrm{C}$ and at $35^{\circ} \mathrm{C}$ in Brucella broth with $2.0 \% \mathrm{NaCl}$ are presented in Table 1 . As can be observed, the killing effect of $2.0 \% \mathrm{NaCl}$ was greater at $35^{\circ} \mathrm{C}$ than at $4^{\circ} \mathrm{C}$ for all the strains studied. The inoculation levels were adjusted to $10^{6}-10^{7}$ cells per $\mathrm{ml}$ of the Brucella broth with $2.0 \% \mathrm{NaCl}$. The mean Campylobacter count decreased by $1.02 \operatorname{logs}(\mathrm{s}=0.72$ ) for human strains and $2.6 \operatorname{logs}(\mathrm{s}=0.85)$ for animal strains at $35^{\circ} \mathrm{C}$. At $4^{\circ} \mathrm{C}$ the mean cell numbers decreased $0.42 \operatorname{logs}(\mathrm{s}=0.37)$ and $0.87 \operatorname{logs}(s=0.45)$, respectively. The mean difference of $\log$ Campylobacter counts before and after incubation in $2.0 \% \mathrm{NaCl}$ both at $35^{\circ} \mathrm{C}$ and $4^{\circ} \mathrm{C}$ were significantly greater $(\mathrm{P}<0.05)$ for the animal strains than for the human strains. The human strains thus exhibited better $\mathrm{NaCl}$ tolerance at both temperatures.

\section{DISCUSSION}

As a rule relatively low concentrations of salt will stimulate the growth of micro-organisms, while higher concentrations inhibit them (Ingram \& Kitchell 1967). In this study, $\mathrm{NaCl}$ concentrations up to $1 \%$ are shown to stimulate the growth of the C. jejuni/coli strains investigated if the incubation temperature used is near the optimum growth temperature. At higher salt concentrations, there are differences in salt tolerance between the strains investigated. Salt concentrations over $1.5 \%$ inhibited growth or were bacteriocidic. The salt-tolerance of C. jejuni/coli is relatively low compared to that of other enteric Gram-negative bacteria. Salmonellae are able to grow at $7-8 \% \mathrm{NaCl}$ in the cultivation medium, if the growth is tested at $37^{\circ} \mathrm{C}$ (Matches \& Liston 1972), and $Y$. enterocolitica is reported to grow in $5 \%$ $\mathrm{NaCl}$ at $25^{\circ} \mathrm{C}$ (Stern et al. 1980).

The tolerance to $3.5 \% \mathrm{NaCl}$ has been used as one criterion in distinguishing $\mathrm{C}$. fetus from C. bubulus and C. fecalis, which usually grow in $3.5 \% \mathrm{NaCl}$ (Smibert 1974). In this study no strains grew at $2 \% \mathrm{NaCl}$, although Fletcher \& Plastridge (1964) reported the growth of certain human strains at this concentration. The cultivation and incubation conditions which they used were not the same as in the present study.

The strains investigated tolerated more $\mathrm{NaCl}$ in the growth medium nearer the optimum growth temperature of $42^{\circ} \mathrm{C}$ (Smi- 
bert 1974) than at $30^{\circ}$ C. Matches \& Liston reported that Salmonella likewise tolerated more salt near the optimum growth temperature than at lower growth temperatures. The range of temperatures and salt concentrations in which Salmonella can grow in much larger than those for Campylobacter. In this study it is shown that the range of salt concentrations at which $\mathrm{C}$. jejuni/ coli can grow is very narrow and that a small change in the salt concentration has a marked effect on the growth.

The best growth at both temperatures investigated was in salt concentrations under $1 \%$. This study indicates that $\mathrm{C}$. jejuni/coli can grow at very low $\mathrm{NaCl}$ concentrations. At a temperature near the minimum growth temperature, the medium without added salt probably even stimulated the growth of some particularly salt-sensitive strains. Whether other subspecies of C. fetus can grow without added salt is not known, but both $\mathrm{C}$. fecalis and many vibrios (it is to be noted that campylobacters were formerly classified in the same genus as vibrios) need salt for growth (Smibert, Shewan \& Veron 1974). The growth in the present Brucella broth, without added salt, can probably be used as a criterion in distinguishing $\mathrm{C}$. fecalis from $\mathrm{C}$. jejuni/coli.

The functioning of sodium chloride in the stimulation or inhibition of bacterial growth is not fully understood. One of its functions in growth inhibition is its ability to decrease the water activity $\left(a_{w}\right)$ in the growth medium. However, a growth medium also contains other solutes which influence the $a_{w}$ (Scott 1957). The theoretical $a_{w}$ value of $\mathrm{NaCl}$ concentrations $0.9 \%$ and $1.7 \%$ in water have been reported to be 0.995 and 0.99 , respectively (Evans \& Niven Jr. 1960). The minimum $\mathrm{a}_{\mathrm{w}}$ for growth of $\mathrm{C}$. jejuni/coli is not known. It is known, however, that bacteria can usually grow at the above range of $a_{w}$. The $a_{w}$ of most moist fresh foods is above 0.99 . It seems unlikely that the relatively low salt concentrations used in this study would alter the $a_{w}$ of Brucella broth so as to be unfavourable for growth of Campylobacter. The limiting $a_{w}$ for the growth of many Gram-negative enteric bacteria is reported to be $0.945-0.95$ (Lee \& Riemann 1971).

The stimulating effect of low concentration of $\mathrm{NaCl}$ on the growth of bacteria may be related to $\mathrm{Na}^{+} . \mathrm{Na}^{+}$is known to have at least two functions in the metabolism of halophilic bacteria (Gow et al. 1981). It is required specifically for the transport of a number of solutes into the cells; it functions also less speci- 
fically, as an osmotic agent, in preventing the loss of intracellular solutes from the cells (MacLeod et al. 1978). Non-halophilic bacteria possess an intracellular tonicity equivalent to that produced by about $0.85-0.9 \% \mathrm{NaCl}$. The other ingredients in the present Brucella broth without added $\mathrm{NaCl}$ probably compensated the need of $\mathrm{NaCl}$ for intracellular tonicity. The $\mathrm{Na}^{+}$concentrations in Brucella broth without added $\mathrm{NaCl}$ was found to be $40 \mathrm{mmol} / \mathrm{l}$ and that in normal Brucella broth $124 \mathrm{mmol} / \mathrm{l}$. The $\mathrm{Na}^{+}$concentration of $40 \mathrm{mmol} / \mathrm{l}$ is probably enough for the metabolic functions of $\mathrm{Na}^{+}$in Campylobacter cells. Since Campylobacter cells are highly salt sensitive, some of the functions of $\mathrm{Na}^{+}$ in the metabolism of cells are probably quite different from those of halophilic bacteria.

This study showed a significant difference in salt-tolerance between strains isolated from humans and animals. Fletcher \& Plastridge (1964) have similarly reported that human isolates of V. fetus tolerated more salt than avian isolates. Stern et al. (1980) investigated environmental and clinical strains of $Y$. enterocolitica and found significant differences in salt and pH-tolerance; the clinical strains were more salt and $\mathrm{pH}$ tolerant than the environmental strains. Whether the difference in salt-tolerance observed in the present study is a general phenomenon or is limited only to the strains investigated remains a question for further studies.

Blaser et al. (1980) recognized that Campylobacter survived better at $4^{\circ} \mathrm{C}$ than at $25^{\circ} \mathrm{C}$ or $37^{\circ} \mathrm{C}$ in water, milk, faecal material, human bile and urine. The present survival studies showed that Campylobacter will survive better at $4^{\circ} \mathrm{C}$ than at $35^{\circ} \mathrm{C}$ in a salt concentration $(2 \%)$ at which they usually do not grow. The same phenomenon is recognized for certain other enteric Gram-negative pathogens. For example Salmonella is rapidly destroyed in curing brines when kept at room temperature, but survives for weeks at $5^{\circ} \mathrm{C}$ (Shipp 1957). E. coli behaves similarly (Ingram \& Kitchell 1967). The survival of Campylobacter at $\mathrm{NaCl}$ concentrations higher than $2 \%$ was not investigated, but in studies by Shipp and Matches \& Liston (1972) there was virtually no difference in the survival of Salmonella at a low temperature when higher or lower salt concentrations were used.

It is known that bacterial cells in the exponential phase of growth rapidly loose viability when cooled ('cold shock') (Sherman \& Albus 1923, Straka \& Stokes 1959). In the present sur- 
vival studies the cells from the stationary phase of growth were transferred to a supporting $2 \% \mathrm{NaCl}$ medium, which then was gradually cooled to $4^{\circ} \mathrm{C}$. Microbial cells, if stored under conditions in which they cannot grow, usually die gradually. The number of Campylobacter cells will remain unchanged for at least 2 days in Brucella broth (own unpublished results) or in other non-inhibitory media (Blaser et al. 1980).

From the practical point of view, the application of the present findings to the survival and growth of Campylobacter in foods with a low salt content is important. If such foods are stored at refrigeration temperatures, Campylobacter will survive but will not grow until the perishable foods are spoiled. Also low salt content in foods will diminish the survival of Campylobacter cells. Perishable foods with a low salt content are not usually stored at temperatures permitting the growth of Campylobacter.

\section{REFERENCES}

Blaser, M. J., H. L. Hardesty \& W.-L. Wang: Survival of Campylobacter fetus subsp. jejuni in biological milieus. J. clin. Microbiol. 1980, $11,309-313$.

Butzler, J. B. \& M. B. Skirrow: Campylobacter enteritis. Clin. Gastroenterol. 1979, 8, 738-765.

Evans, J. B. \& C. F. Niven Jr.: Microbiology of meat: Bacteriology. In: The Science of Meat and Meat Products. W. H. Freeman \& Co, San Francisco 1960.

Fletcher, R. D. \& W. N. Plastridge: Difference in physiology of Vibrio spp. from chickens and man. Avian Dis. 1964, 8, 72-75.

Gow, J. A., R. A. MacLeod, M. Goodbody, D. Frank \& L. DeVoe: Growth characteristics at low $\mathrm{Na}^{+}$concentration and the stability of the $\mathrm{Na}^{+}$requirement of a marine bacterium. Canad. J. Microbiol. 1981, 27, 350-357.

Grant, I. H., N. J. Richardson \& V. D. Bokkenheuser: Broiler chickens as potential source of Campylobacter infections in humans. $J$. clin. Microbiol. 1980, 11, 508-510.

Hänninen, M.-L.: Characterization of Campylobacter jejuni/coli isolated from different sources. To be published.

Hänninen, M.-L. \& M. Raevuori: Occurrence of Campylobacter fetus subsp. jejuni and Y. enterocolitica in domestic animals and in some foods of animal origin in Finland. Nord. Vet.-Med. 1981, $33,441-445$.

Ingram, M. \& A. C. Kitchell: Salt as a preservative for foods. J. Food Technol. 1967, 2, 1-15.

Ingram, M. \& B. M. MacKey: Inactivation by cold. In: Inhibition and Inactivation of Vegetative Microbes. Skinner, F. A. \& W. B. Hugo (eds.). Academic Press 1976, pp. 111-151. 
Lawson, G. H. K., A. C. Rowland \& P. Wooding: The characterisation of Campylobacter sputorum subspecies mucosalis isolated from pigs. Res. Vet. Sci. 1975, 18, 121-126.

Lee, W. H. \& H. Riemann: The inhibition and destruction of Enterobacteriaceae of pathogenic and public health significance. In: Inhibition and Destruction of the Microbial Cell. W. B. Hugo (ed.). Academic Press, New York, N.Y. 1971, p. 399.

MacLeod, R. A., M. Goodbody \& J. Thomason: Osmotic effects on membrane permeability in a marine bacterium. J. Bact. 1978, 133, $1135-1143$.

Matches, J. R. \& J. Liston: Effects of incubation temperature on the salt tolerance of Salmonella. J. Milk Food Technol. 1972, 35, $39-44$.

Pearson, A. D., W. G. Suckling, I. D. Ricciardi, M. Knill \& E. Ware: Campylobacter-associated diarrhea in Southampton. Brit. med. J. 1977, ii, 955-956.

Scott, W. J.: Water relations of food spoilage micro-organisms. Advanc. Food Res. 1957, 7, 83-127.

Sherman, J. M. \& N. R. Albus: Physiological youth in bacteria. J. Bact. 1923, 8, 123-139.

Shewan, J. M. \& M. Veron: Genus Vibrio. In: Bergey's Manual of Determinative Bacteriology. Buchanan, R. E. \& N. E. Gibbons (eds.). 8th Ed. Williams \& Wilkins, Baltimore 1974, pp. 340345.

Shipp, $H$. L.: Survival of Salmonella enteritidis in brine. Proceedings of a Symposium on The Microbiology of Fish and Meat Curing Brines, London 1957.

Smibert, R. M.: Campylobacter. In: Bergey's Manual of Determinative Bacteriology. Buchanan, R. E. \& N. E. Gibbons (eds.). 8th Ed. Williams \& Wilkins, Baltimore 1974, pp. 207-211.

Stern, N. J., M. D. Pierson \& A. W. Kotula: Effects of $\mathrm{pH}$ and sodium chloride on Yersinia enterocolitica growth at room and refrigeration temperature. J. Food Sci. 1980, 45, 64-67.

Stern, N. J.: Campylobacter fetus spp. jejuni: Recovery methodology and isolation from lamb carcasses. J. Food Sci. 1981, 46, 660663.

Straka, R. P. \& J. L. Stokes: Metabolic injury to bacteria at low temperature. J. Bact. 1959, 78, 181-185.

\section{SAMMANFATTNING}

Effekten av NaCl p̊̊ Campylobacter jejuni/coli.

Växten av 2 stammar av C. jejuni/coli (5616, B33) i Brucella brot med 0 till $2 \% \mathrm{NaCl}$ under $48 \mathrm{~h}$ undersöktes. Båda bakteriestammarna visade en bättre salt tolerans i $35^{\circ} \mathrm{C}$ än i $30^{\circ} \mathrm{C} .2 \% \mathrm{NaCl}$ var bakteriocid $i$ de båda använda temperaturerna. Bakteriestammarna växte också i näringsubstratet utan $\mathrm{NaCl}$ tillsats. Låga konsentrationer av 
salt stimulerade växten av stammen 5616 i $35^{\circ} \mathrm{C}$, men inte växten av stammen B33. I inkubationstemperaturen $30^{\circ} \mathrm{C}$ växte stammen 5616 i salt konsentrationer upp till $1.0 \%$ och stammen B33 i medium utan $\mathrm{NaCl}$ tillsats ocr i medium med $0.5 \% \mathrm{NaCl}$.

Inverkan av $2 \% \mathrm{NaCl}$ på överlevandet av C. jejuni/coli stammar i $4^{\circ} \mathrm{C}$ och $35^{\circ} \mathrm{C}$ undersöktes också. De stammar som isolerats från människor hade signifikant bättre salt tolerans än stammarna isolerade från husdjur. På grund av resultaten av denna undersökning kan man anta, att saltningen är effektiv för att förhindra av växten eller överlevandet av C. jejuni/coli i livsmedel.

(Received October 31, 1981).

Reprints may be requested from: Marja-Liisa Hänninen, the Department of Food Hygiene, College of Veterinary Medicine, Hämeentie 57, 00550 Helsinki 55, Finland. 